\title{
IMPLEMENTASI WEBSITE RIC SEBAGAI MEDIA PENUNJANG KEEFEKTIFAN RAHARJA CAREER PADA PERGURUAN TINGGI
}

\author{
Untung Rahardja ${ }^{1}$, Tuti Nurhaeni ${ }^{2}$, Dian Maharani Damanik ${ }^{3}$ \\ ${ }^{1,2,3}$ Universitas Raharja \\ 1,2,3 Jl. Jendral Sudirman No. 40 Modern Cikokol Tangerang \\ Iuntung@raharja.info,2tuti@raharja.info,32dian.maharani@raharja.info
}

\begin{abstract}
Abstrak-Raharja Career merupakan pameran hasil karya penelitian yang telah dilakukan oleh Pribadi Raharja sebelum sidang. Selain diperuntukkan untuk mahasiswa tingkat akhir, Raharja Career juga menjadi tugas mandiri bagi seluruh mahasiswa-mahasiswi Perguruan Tinggi Raharja. Raharja Internet Cafe (RIC) ialah fasilitas pada Perguruan Tinggi Raharja yang dikhususkan untuk membantu kegiatan perkuliahan. Sebagai salah satu fasilitas penting, RIC tentu ikut andil dalam event Raharja Career. Sayangnya transaksi yang digunakan masih konvensional. Tentunya hal ini sangatlah tidak efektif karena akan mengakibatkan penumpukan antrian dan menghabiskan banyak waktu. Untuk mengatasi problem tersebut, dikembangkan lah website e-commerce RIC dengan menyediakan pemesanan Form Raharja Career secara online. Dalam penelitian ini ditemukan 2 (dua) permasalahan pada sistem sebelumnya dan didukung 4 (empat) metode penelitian yaitu metode observasi, studi pustaka, analisis SWOT dan implementasi. Dengan adanya penelitian ini diharapkan dapat mengatasi permasalahan yang ada sehingga proses keberlangsungan event Raharja Career dapat lebih efektif dan efisien.
\end{abstract}

Kata Kunci- Raharja Career, Raharja Internet Cafe, E-Commerce.

Abstract-Raharja Career is an exhibition of the results of research work carried out by Pribadi Raharja before the trial. Aside from being intended for final year students, Raharja Career is also an independent task for all Raharja College students. Raharja Internet Cafe (RIC) is a facility at the Raharja College which is dedicated to assisting lecture activities. As one of the important facilities, RIC certainly takes part in the Raharja Career event. Unfortunately the transaction used is still conventional. Of course this is very ineffective because it will cause a build-up of queues and spend a lot of time. To overcome this problem, RIC's e-commerce website was developed by providing online Career Order ordering. In this study 2 (two) problems were found in the previous system and supported by 4 (four) research methods, namely observation, literature study, SWOT analysis and implementation. The existence of this research is expected to be able to overcome the existing problems so that the sustainability process of the Raharja Career event can be more effective and efficient.

Keywords-Raharja Career, Raharja Internet Cafe, E-Commerce.

\section{PENDAHULUAN}

Industri perekonomian memegang peranan penting dalam menentukan kualitas suatu bangsa. Semakin maju tingkat perekonomian suatu negara maka semakin dihargai kedudukan negara tersebut. Seiring dengan perkembangan zaman, sistem perekonomian akan terus mengalami proses pembaharuan. Perkembangan yang ada pun mendorong kita untuk terus belajar dan mencoba mengimbangi dengan perubahan-perubahan yang ada agar tidak tertinggal terlalu jauh [1] Berdasarkan hal tersebut dapat disimpulkan bahwa sistem perekonomian dapat berubah sesuai dengan perkembangan pola pikir masyarakat yang didukung dengan adanya teknologi informasi. Saat ini teknologi informasi banyak diterapkan dalam berbagai bidang. Salah satunya ialah untuk pemasaran. Dengan memanfaatkan teknologi yang ada, jangkauan pemasaran produk akan lebih luas dan produk yang ditawarkan pun lebih mudah di diterima oleh konsumen karena bentuk informasi yang lebih lengkap dan informatif. E-commerce (electronic commerce) merupakan sebuah cara pembayaran, pembelian, penjualan, pemasaran barang dan jasa melalui sistem elektronik seperti internet. E-commerce dapat melibatkan pertukaran data elektronik, transfer dana elektronik, sistem manajemen inventory otomatis serta sistem pengumpulan data otomatis [2].

Pada detik ini, setiap perguruan tinggi yang ada dituntut untuk bersaing secara global [3]. Salah satu kunci keberhasilan persaingan global terletak pada bagaimana pelayanan yang efisien dan cepat dapat diberikan oleh perguruan tinggi kepada mahasiswa [4]. Pelayanan yang optimal akan meningkatkan proses pembelajaran, juga dapat memperbaiki sistem 
pembelajaran yang sudah diterapkan. Perguruan Tinggi Raharja merupakan salah satu institusi pendidikan yang bergerak di bidang teknologi informasi. Oleh karena itu, Perguruan Tinggi Raharja terus menerus melakukan peningkatan dan pengembangan baik berupa sistem

Page | 14 pembelajaran kampus atau sistem pelayanan kampus yang telah ada pada Perguruan Tinggi Raharja [5].

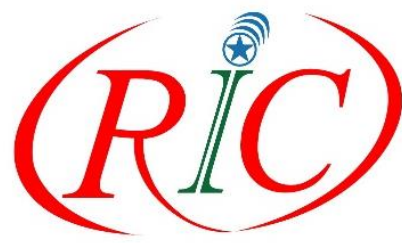

Gbr. 1 Logo Raharja Internet Cafe (RIC)

RIC (Raharja Internet Cafe) merupakan sebuah fasilitas yang diberikan oleh Perguruan Tinggi Raharja guna menunjang kebutuhan mahasiswa dalam membantu kegiatan perkuliahan. RIC menyediakan kebutuhan mahasiswa seperti Upgrade iPad, Instal software terbaru untuk iPad, Aksesoris iPad dan Laptop, service iPad dan Laptop dan kebutuhan lainnya. RIC juga memfasilitasi mahasiswa Perguruan Tinggi Raharja dengan ruangan yang nyaman, menyediakan berbagai minuman, printing, scan, dan SIS (Sistem Informasi Student). RIC juga melayani mahasiswa yang akan menjalani Raharja Career, seperti menyediakan buku tamu peserta, kartu nama peserta Raharja Career, souvenir dan RIC pun menerima paket print dan Hard Cover untuk mahasiswa yang sedang menjalankan KKP (Kuliah Kerja Praktek), Tugas Akhir (TA)/Skripsi [6].

Dengan banyaknya fasilitas yang diberikan RIC tentunya banyak mahasiswa Universitas Raharja yang menjadi pelanggan RIC, namun RIC masih mempunyai kendala dalam menyajikan informasi penjualan produknya, sehingga kurang optimalnya layanan pemasaran dan transaksi di RIC. Hal ini dikarenakan sistem transaksi pada RIC belum berjalan secara online. Tentunya hal ini menjadi sebuah kekurangan bagi RIC yang masih menggunakan metode konvensional dalam pelaksanaan layanan transaksinya. Seperti contoh ialah pemesanan form Raharja Career. Raharja Career merupakan pameran hasil karya penelitian oleh Pribadi Raharja yang telah menyelesaikan TA/Skripsi-nya di Perguruan Tinggi Raharja. Hasil karya yang dipamerkan berupa demo program, alat robotik, maupun video presentasi. Dengan membawa form Raharja Career ini mahasiswa atau pengunjung stand dapat melakukan observasi langsung terhadap produk yang dihasilkan. Banyaknya mahasiswa yang ingin mencetak form membuat RIC ramai pengunjung sehingga terjadinya penumpukan antrian serta human error dalam pelaksanaannya. Hal ini tentunya menjadi masalah yang harus dipecahkan bagi sebuah instansi pendidikan untuk memberikan kenyamanan pada mahasiswanya[7]. Untuk mengatasi hal tersebut maka dikembangkan lah website RIC yang menangani pemesanan secara online untuk menunjang keefektifan keberlangsungan acara Raharja Career.

\section{METODE PENELITIAN}

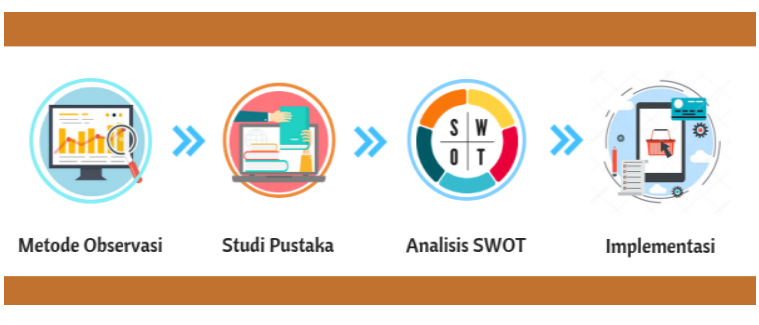

Gbr. 2 Metode Penelitian

Metode penelitian adalah aktivitas yang dilakukan oleh peneliti sebelum merancang sistem sebagai upaya untuk menganalisa permasalahan yang ada, dan juga memudahkan peneliti dalam mengatasi permasalahan[8]. Peneliti melakukan beberapa tahapan dalam penelitian[9]. Terdapat 4 (empat) teknik penelitian yang digunakan demi kelancaran proses penelitian, yaitu metode observasi, analisis SWOT, metode studi pustaka dan implementasi

1. Metode Observasi merupakan metode pengamatan pada sistem yang berkaitan dengan penelitian. Sehingga diperoleh data akurat yang dapat digunakan sebagai informasi lebih lanjut dalam melakukan penelitian. Pada tahap ini dilakukan penelitian langsung terhadap sistem Raharja Internet Cafe saat berlangsungnya event Raharja career.

2. Analisis SWOT adalah suatu cara menganalisis faktor-faktor internal dan eksternal menjadi langkah-langkah strategi dalam pengoptimalan usaha yang lebih menguntungkan. Dalam analisis faktor-faktor internal dan eksternal akan ditentukan aspek-aspek yang menjadi kekuatan (Strengths), kelemahan (Weakness), kesempatan (Opportunities), dan yang menjadi ancaman (Threat) sebuah organisasi. Dengan begitu akan dapat ditentukan berbagai kemungkinan alternatif strategi yang dapat dijalankan (Freddy Rangkuti, 2005:19 dalam Jurnal Manajemen Industri dan 
Logistik tahun 2018)[10]. Dalam penggunaan metode ini peneliti melakukan pengklasifikasian data juga faktor apa saja yang termasuk kedalam kekuatan, kelemahan, kesempatan, juga ancaman yang berkaitan dengan tema penelitian.

3. Metode Studi Pustaka. Literature Review atau studi pustaka adalah pencarian sumber-sumber atau opini pakar tentang suatu hal yang berkaitan dengan tujuan penelitian[11]. Pada tahap ini, peneliti berhasil merangkum beberapa literature review untuk mendukung adanya penelitian. Berikut 7 (tujuh) literature review yang pernah dilakukan sebelumnya, diantaranya ialah :

1. Penelitian yang dilakukan oleh Himawan, Asep Saefullah dan Sugeng Santoso dari STMIK Raharja, Tangerang pada tahun 2014, yang berjudul "Analisa dan Perancangan Sistem Informasi Penjualan Online (E-Commerce) pada CV Selaras Batik Menggunakan Analisis Deskriptif'[12]. Pada penelitian ini membahas tentang website ecommerce pada CV Selaras Batik yang memanfaatkan internet sebagai media pemasaran dimana dapat memudahkan pemilik toko untuk memberikan pelayanan terhadap konsumen secara optimal dan memberikan informasi 24 jam serta dapat diakses kapan saja dan dimana saja.

2. Penelitian yang dilakukan oleh Untung Rahardja, Qurotul Aini dan Fitri Faradilla pada tahun 2018 dengan judul "Implementasi Viewboard Berbasis Interaktif Javascript Charts Pada Sistem Penilaian Perkuliahan"[13]. Pada penelitian ini membahas tentang viewboard yang dapat menampilkan penilaian terhadap mahasiswa secara online sehingga dapat diakses dimana saja dan kapan saja.

3. Penelitian yang dilakukan oleh Po Abas Sunarya, Doucette David Bernard dan Dian Maharani Damanik tahun 2019 dengan judul "Viewboard Implementation Based on Javascript Charts As a Media for Submitting Sales Information on a Green E-Commerce Website Light Cafe"[14]. membahas tentang penerapan viewboard Green Light Cafe untuk mempermudah penyajian informasi terhadap top management dan staff.

4. Penelitian dilakukan oleh Untung Rahardja, Eka Purnama Harahap, Dini Intan Pratiwi, pada tahun 2018 dengan judul "Pemanfaatan Rinfosheet Sebagai Media Informasi Laporan Penjualan Barang Pada Raharja Internet Cafe"[15]. Penelitian ini membahas bahwa Rinfosheet lebih memudahkan user dibandingkan dengan Ms. Excel karena dapat digunakan dan disimpan secara online serta dapat diakses melalui komputer atau ponsel kapan saja dan dimana saja.

5. Penelitian yang dilakukan oleh Henderi, Harph Zcull, dan Cheetah Savana Putri tahun 2019 dengan judul "Utilization of Testimonials Menu as Submission Media Information on Buyer Satisfaction on the Website E-Commerce Raharja Internet Cafe"[16]. membahas tentang Pemanfaatan website Raharja Internet Cafe (RIC) sebagai media untuk mengukur tingkat kepuasan customer melalui menu testimonials.

6. Penelitian yang dilakukan oleh Omprakash Yadav dan Bhikaji Ghadigaonkar pada tahun 2016, yang berjudul "E-Commerce Website on Medical and Pharmacy"[17]. Pada penelitian ini membahas mengenai pembuatan website e-commerce untuk apotek Medical and Pharmacy, dengan adanya website e-commerce ini pelanggan dapat mencari dan melakukan transaksi pembelian obat melalui website dari mana saja dan kapan saja. Serta melalui website ini pelanggan atau pasien dapat meminta saran dari Dokter langsung tentang produk/obatobatan yang harus dibeli. Tujuan dari penelitian ini yaitu evolusi dalam belanja online Obat medis, agar meminimalkan upaya dan menghemat waktu untuk membeli obat.

7. Penelitian yang dilakukan oleh Renaldi Aulia Sani dan Lalang Erawan dari Universitas Dian Nuswa, Semarang pada tahun 2017, yang berjudul "Perancangan Sistem Informasi Penjualan Online Barang Graffiti Pada Toko Outline Graff Store Semarang"[18]. Pada penelitian ini membahas tentang sistem e-commerce pada Outline Graff Store, dimana sistem ecommerce tersebut berfungsi sebagai sarana informasi kepada konsumen, serta menjadi media promosi bagi perusahaan dan juga dapat menjual produk-produk yang ada pada perusahaan sehingga penjualan pun semakin efektif dan efisien. 
4. Implementasi

Implementasi merupakan suatu penerapan terhadap hal yang sudah direncanakan. Pada penelitian ini sudah dilakukan implementasi dengan memasukkan menu Raharja Career pada Website RIC untuk menunjang keefektifan event Raharja Career.

\section{HASIL DAN PEMBAHASAN}

Hasil penelitian yang dihasilkan ialah sebuah menu khusus untuk Raharja Career yang dapat diakses pada website RIC, dimana pada menu tersebut ditampilkan 2 produk yakni Buku Tamu, dan Form Raharja Career untuk memenuhi kebutuhan event tersebut. Tidak hanya pada laptop, Website E-Commerce Raharja Internet Cafe (RIC) dapat diakses menggunakan ipad maupun Handphone. Semua orang dapat mengakses website RIC langsung dari rumah maupun dimana saja. Penggunaan website e-commerce (electronic commerce) dapat membantu pelanggan dalam kegiatan transaksi tanpa harus datang ke tempat ataupun mengantri [20]. Selain itu tampilan user-friendly pada website juga sangat mempermudah customer dalam melakukan transaksi. Berikut merupakan tahapan dalam memesan produk Raharja Career dalam website RIC.

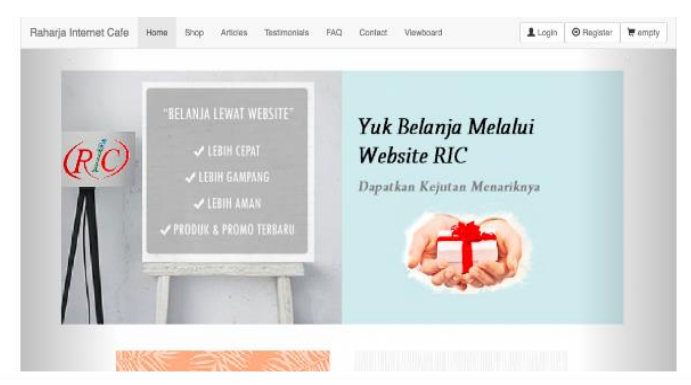

Gbr. 3 Homepage website Raharja Internet Cafe

Homepage website RIC terdiri dari 7 (tujuh) bagian yakni, Home, shop, articles, testimonials, FAQ, contact dan viewboard. Selain itu terdapat menu login, register dan check out. Untuk melengkapi tampilan, pada menu ini ditampilkan Banner dengan menginformasikan 4 kelebihan website.

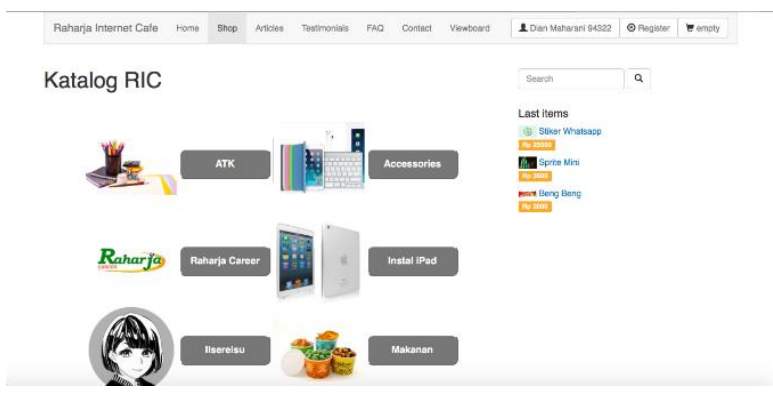

Gbr. 4 Katalog Website Raharja Internet Cafe

Pada menu ini ditampilkan beberapa pilihan product, diantaranya ialah alat tulis kantor (ATK), accesories, install ipad, ilsereisu, makanan, minuman, komputer, print, dan pengembangan produk baru yakni Raharja Career.

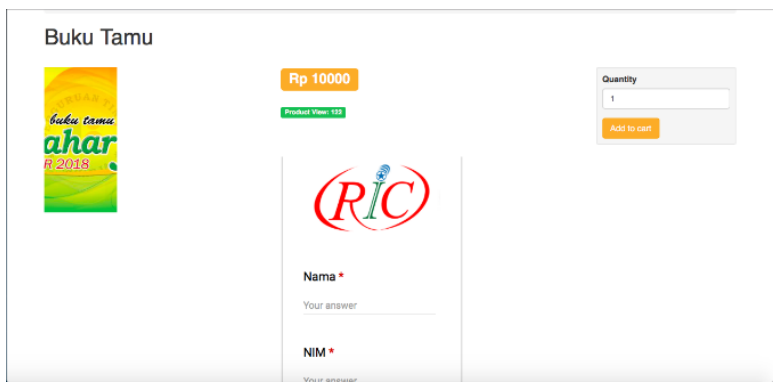

Gbr. 5 Pilihan Produk Raharja Career

Terdapat 2 (dua) pilihan produk yang ditawarkan dari menu Raharja Career, diantaranya ialah Buku Tamu dan Form pengunjung Raharja Career. Form ini dikhususkan untuk pengunjung stand yakni mahasiswa untuk mengobservasi produk yang ditampilkan sedangkan Buku Tamu merupakan buku yang berisi daftar pengunjung selama kegiatan berlangsung. Buku ini digunakan sebagai bukti bahwa mahasiswa telah mengobservasi produk yang dibuat serta tolak ukur seberapa banyak mahasiswa yang mengunjungi stand.
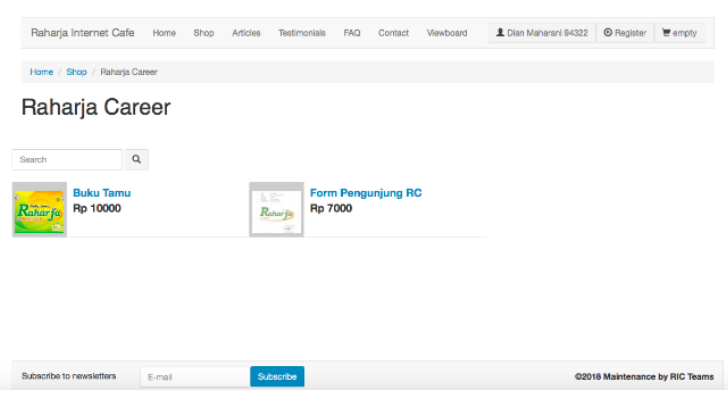

Gbr. 6 Formulir Pemesanan 
Selanjutnya adalah rincian produk disertai dengan form pembelian. Formulir online ini berfungsi untuk mengumpulkan data-data penting dari pembeli, seperti nama, nim, dan jumlah buku yang ingin dibeli. Dengan adanya formulir ini, pembeli dapat menginformasikan Page | 17 keinginan pesanan secara efektif dan efisien.

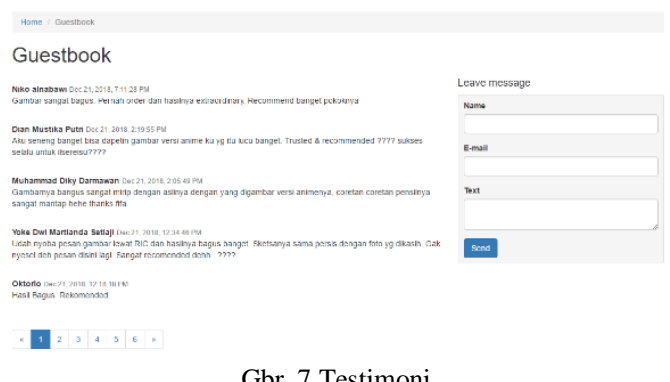

Setelah menyelesaikan transaksi, pembeli dapat memberikan testimoni berupa tulisan mengenai pelayanan pada Raharja Internet Cafe. Dengan adanya testimoni ini diharapkan dapat mengukur kepuasan customer dalam melakukan transaksi. Selain itu, adanya kritik dan saran dapat memberikan RIC peluang untuk menjadi lebih baik dimasa yang akan datang.

\section{KESIMPULAN}

Berdasarkan hasil penelitian yang dilakukan, maka dapat ditarik 3 (tiga) kesimpulan, yakni :

1. Memaksimalkan keefektifan event Raharja Career dikarenakan mahasiswa telah memiliki form berdasarkan pemesanan online.

2. Proses pemesanan form secara online dapat mempermudah pelayanan pada Raharja Internet Cafe

3. Meminimalisir terjadinya human error, karena jika transaksi masih dilakukan secara konvensional penginputan nim dan nama mahasiswa seringkali salah sehingga terjadinya penumpukan antrian juga kurang efektif dan efisien.

\section{UCAPAN TERIMA KASIH}

Peneliti mengucapkan terima kasih kepada Universitas Raharja yang telah mendukung terlaksananya penelitian ini.

\section{REFERENSI}

[1] Raharja, U., Lutfiani, N., \& Wardana, W. S. (2018). Penjadwalan Agenda Pelaksanaan Tridharma Perguruan Tinggi Secara Online Menggunakan Google Calendar. Jurnal Teknoinfo, 12(2), 66-71.

[2] Komputer, W. (2015). Membuat Toko Online dengan Wordpress dan WP E-Commerce. Elex Media Komputindo.

[3] Warsito, A. B., \& Yusup, M. (2014). Kajian Yii Framework dalam Pengembangan Website Perguruan Tinggi. CCIT Journal, 7(3), 437-451.

[4] Rahardja, U., Aini, Q., \& Faradilla, F. (2018). IMPLEMENTASI VIEWBOARD BERBASIS INTERAKTIF JAVASCRIPT CHARTS PADA WEBSITE E-COMMERCE PERGURUAN TINGGI. Jurnal Dinamika Informatika, 7(2), 1-18.

[5] Rahardja, U., Harahap, E. P., \& Pratiwi, S. (2018). Pemanfaatan Mailchimp Sebagai Trend Penyebaran Informasi Pembayaran Bagi Mahasiswa Di Perguruan Tinggi. Technomedia Journal, 2(2), 41-54.

[6] Raharja, U., Harahap, E. P., \& Devi, R. E. C. (2018). Pengaruh Pelayanan dan Fasilitas pada Raharja Internet Cafe Terhadap Kegiatan Perkuliahan Pada Perguruan Tinggi. Jurnal Teknoinfo, 12(2), 60-65.

[7] Ilamsyah, I., Katz, R., \& Fitriani, R. R. The Web-based Internet Cafe (RIC) Raharja Ordering System. Aptisi Transactions on Technopreneurship, 1(1), 93-100.

[8] Aini, Q., Rahardja, U., \& Naufal, R. S. (2018). Penerapan Single Sign On dengan Google pada Website berbasis YII Framework. Sisfotenika, 8(1), 57-68.

[9] Santoso, S., Kauffman, R. J., \& Aristo, N. C. (2019). The Information System of Name Card Sales Based on Digital Marketing to Improve Creativepreneur on College ECommerce Website. Aptisi Transactions on Technopreneurship, 1(1), 71-81.

[10] Wicaksono, A. (2017). Strategi Pemasaran dengan menggunakan Analisis SWOT Tanpa Skala Industri Pada PT X Di Jakarta. Jurnal Manajemen Industri dan Logistik, 1(2), 192-201.

[11] Djiwandono, P. I. (2015). Meneliti itu Tidak Sulit: Metodologi Penelitian Sosial dan Pendidikan Bahasa. Deepublish.

[12] Himawan, H., Saefullah, A., \& Santoso, S. (2014). Analisa dan Perancangan Sistem Informasi Penjualan Online (ECommerce) pada CV Selaras Batik Menggunakan Analisis Deskriptif. Scientific Journal of Informatics, 1(1), 53-63.

[13] Rahardja, U., Aini, Q., \& Faradilla, F. (2018). IMPLEMENTASI VIEWBOARD BERBASIS INTERAKTIF JAVASCRIPT CHARTS PADA WEBSITE E-COMMERCE PERGURUAN TINGGI. Jurnal Dinamika Informatika, 7(2), 1-18.

[14] Sunarya, P. A., Jusoh, Z. M., \& Damanik, D. M. (2019). Viewboard Implementation Based on Javascript Charts as a Media for Submitting Sales Information on a Green ECommerce Website Light Cafe. Aptisi Transactions on Technopreneurship, 1(1), 12-21.

[15] Rahardja, U., Harahap, E. P., \& Pratiwi, D. I. (2018). Pemanfaatan RinfoSheet Sebagai Media Informasi Laporan Penjualan Barang pada Raharja Internet Cafe. Jurnal Ilmiah Teknologi Informasi Asia, 12(1), 65-74.

[16] henderi, henderi, harrison, robert, \& Putri, C. (2019). Utilization of Testimonials Menu as Submission Media Information on Buyer Satisfaction on the Website ECommerce Raharja Internet Café. Aptisi Transactions On Technopreneurship (ATT), 1(1), 101-108. Retrieved from https://pandawan.aptisi.or.id/index.php/att/article/view/35 
[17] Yadav, O., \& Ghadigaonkar, B. (2016). E-Commerce Website on Medical and Pharmacy. Imperial Journal of Interdisciplinary Research, 2(5).

[18] Sani, R. A., \& Erawan, L. (2017). Perancangan Sistem Informasi Penjualan Online Barang Graffiti Pada Toko Outline Graff Store Semarang. JOINS (Journal of Information System),

Page | 18 2(1), 57-66.

[19] Hariguna, T., Yusup, M., \& Priyadi, A. (2019). The Transaction Optimization Of Color Print Sales Through ECommerce Website Based On Yii Framework On Higher Education. Aptisi Transactions On Technopreneurship (ATT),
$1(1)$
$1-10$.
Retrieved
from

https://pandawan.aptisi.or.id/index.php/att/article/view/60

[20] Rahardja, U., Aini, Q., \& Sartika, D. (2015). Build A Business

To Customer Online Store Using Airzone Content Management System. CCIT Journal, 8(2), 112-122. 